\title{
THE PRICE OF PUBLICITY
}

\section{David Capper, Reader in Law, Queen's University Belfast}

These are not very good days for airlines. The main international and flagship carriers have been very badly hit by September 11, the downturn in the world economy, and most recently the second Gulf War and the virulent strain of pneumonia originating in south and east Asia. US Airways has just unwillingly emerged from chapter 11, United Airlines is deeply entangled in the same bankruptcy proceeding and may only exit via chapter 7 (liquidation), American Airlines is desperately trying to avoid bankruptcy, and even British Airways has had to resort to massive redundancies. Many of the problems of the larger carriers could be management issues to do with high salary costs and unnecessary frills. In relation to these the budget, low cost airlines are commonly viewed as having an advantage, although these carriers do not have to meet the challenges of long haul inter-continental travel. Consequently they appear to have been less badly affected by the recent troubles in the airline industry. However theirs' remains a very competitive business and Ryanair could certainly have done without the kind of publicity "own goal" generated by the case reviewed in this note.

Jane O'Keeffe $\mathrm{v}$ Ryanair Holdings plc ${ }^{1}$ was a tale of a publicity ploy gone badly wrong. The plaintiff was supposedly the one millionth passenger ever to travel with Ryanair when she flew from Dublin to London on $20^{\text {th }}$ October 1988. In fact there is no good reason to believe that she was the one millionth passenger. Ryanair knew that their one millionth passenger would fly with them some time during the week in which $20^{\text {th }}$ October 1988 fell. When the plaintiff checked in for her London flight on $20^{\text {th }}$ October she was asked if she would like "to be" the one millionth passenger. The prize for this was that she got free flights with Ryanair to any location it flew to for life for herself and a named companion. This was not a gift because the plaintiff had to agree to participate in publicity to mark the occasion. Much publicity was generated because the event was featured on television and radio news bulletins that day and in the national newspapers in Ireland. The plaintiff was at the time a 21 year old secretary. The judgment does not say whether she was photogenic but it is a fair inference that Ryanair would not have chosen her were she not. The whole episode resembled a kind of budget Carbolic Smoke Ball. ${ }^{2}$ Instead of making an "offer to the world" of free flights to whoever actually turned out to be the one millionth passenger to fly with Ryanair, the defendant picked out someone from the crowd that they thought would serve their publicity purposes. When they reneged on the deal nine years later they discovered that the plaintiff was no pushover and they suffered a defeat in a high profile court case which must do some damage to themselves (and, perhaps, other low cost airlines) at a time when they could conceivably capitalise upon the difficulties being experienced by the larger carriers.

1 [2003] 1 ILRM 14.

2 Carlill v Carbolic Smoke Ball Co [1893] 1 QB 256. 
Why the defendants chose to challenge the plaintiff's right to free air travel is by no means apparent. It may have been that after nine years they felt they had got enough out of the arrangement and that the plaintiff would be satisfied with what she'd got and create no fuss. They seem to have taken the position that as there was nothing in writing there was no contract. The plaintiff thus had to prove the existence of the contract through oral testimony. There were several sharp conflicts of evidence between the plaintiff and the defendants' witnesses, including the chief executive ( $\mathrm{Mr}$ Michael O'Leary). The judge (Kelly J) resolved every one of these conflicts in favour of the plaintiff, including one where the plaintiff alleged and $\mathrm{Mr}$ O'Leary denied that he acted in a hostile, aggressive and bullying manner towards her. The judge held that Ryanair had broken its contract with the plaintiff and had to pay damages in the sum of 67,500 Euro. The first element in this was a sum of 6,000 Euro for the loss of free travel from 1997 (when the defendants reneged on the contract) until the trial in 2002. This was arrived at by taking the average return fair for Ryanair of 150 Euro per person, and an average of four return journeys a year (the plaintiff's average from 1988 to 1997), for these five years. The second element was 60,000 Euro. The judge assumed here that as the plaintiff and her husband got older and their children grew up they would be likely to travel more, ten trips a year being a not unreasonable estimate. It was further assumed that the cost of air travel would continue to reduce and 120 Euro per return flight was taken as a reasonable estimate of average fares. The number of years of travel was taken as 25 , not unlike the figure taken as the multiplier for personal injury awards. The final element was 1,500 Euro for disappointment, frustration and upset arising out of the loss of a holiday weekend in October 1997 (when Ryanair reneged) and the "unpleasant and shabby treatment" the plaintiff suffered on that occasion.

Although the main significance of the case lies in the adverse publicity for Ryanair there were two important legal issues worthy of comment.

\section{Consideration}

One of Ryanair's defences to the plaintiff's claim was that, if there was any agreement between the parties, there was no enforceable contract because Ryanair's promise to provide free flights was not supported by consideration moving from the plaintiff. Kelly $\mathrm{J}$ had little trouble dismissing this argument. The plaintiff's agreement to participate in publicity was a benefit to the defendants (why else would they have asked her to do this?) and a detriment to her because she had to surrender her anonymity and privacy. ${ }^{3}$ Arguments about the insufficiency of consideration are not likely to get too far at the contractual formation stage. Today they seem only to arise in the context of contractual variations and even here the part payment of debt rule is effectively the only one left standing. Williams $\mathrm{v}$ Roffey Bros and Nicholls (Contractors) $\mathrm{Ltd}^{4}$ virtually abolishes the pre-existing duty rule and effectively holds that any "practical benefit" for a promisor offering more for an already due return contractual performance will meet the requirement for consideration. In other words the courts take the view that it is up to the

3 [2003] 1 ILRM 14, at 25.

4 [1991] 1 QB 1. 
parties to decide what is of benefit to them, subject only in the contractual variation situation to any argument about duress or other unconscionable conduct. In the contractual formation situation it is not at all likely that the courts will readily entertain an argument that something specifically requested does not amount to sufficient consideration.

Before leaving this issue it may be worth considering the status of cases where requested benefits were of an even more ethereal quality than the positive publicity of O'Keeffe $\mathrm{v}$ Ryanair. In particular what does this case say about promises to stop complaining, ${ }^{5}$ or to abstain from alcohol and tobacco? ${ }^{6}$ What does it say about the Northern Ireland Court of Appeal's refusal to recognise as consideration the promise of a religious order to pray for an architect who did work for it? ${ }^{7}$ It is suggested that the courts would find themselves in an impossible position if they tried to judge the sufficiency of these considerations on a case by case basis. They would be in almost as difficult a position if they tried to formulate some objective test for distinguishing these cases from Williams v Roffey and O'Keeffe v Ryanair. It would be better to recognise the value of party autonomy and afford the status of sufficient consideration to anything a person of sound mind and not subject to any unconscionable influence was prepared to pay for. Neither should courts dwell much on the question whether this is a benefit to the promisor or a detriment to the promisee. If it is requested by the promisor then in the absence of anything suggesting this party could not exercise a free choice it should be recognised as good and sufficient consideration. That does not mean that all such "promises" would be enforceable. The doctrine of intention to create legal relations could be invoked to deny contractual status to some of these agreements. Thus promises like those made in O'Neill v Murphy and O'Keeffe v Ryanair should normally be enforced because the nature of the transaction is commercial. Promises like those made in White $\mathrm{v}$ Bluett and Hamer $\mathrm{v}$ Sidway should require stronger evidence that they were intended to be legally binding because the transaction is between family members.

In those cases where the benefit derived by the promisor or the detriment suffered by the promisee is not requested and is an accidental result of a promise there should be no finding of sufficient consideration. These are the classic sorts of cases in which the doctrine of estoppel can operate. At the moment English law probably provides a less comprehensive remedial regime for these cases than does the jurisprudence of the American and Australian courts. English promissory estoppel seems mainly to provide the promisee with a defence if the promisor takes legal action inconsistently with the promise. ${ }^{8}$ American jurisprudence seems to allow the promisee to bring an action for breach of the promise but may limit the remedy to something

5 White v Bluett (1853) 23 LJ Ex 36 (no consideration here).

${ }^{6}$ Hamer v Sidway (1891) 27 NE 256 (consideration provided here).

7 O’Neill v Murphy [1936] NI 16.

8 See Combe v Combe [1951] 2 KB 215. Cf R Halson, "The Offensive Limits of Promissory Estoppel” (1999) LMCLQ 256. 
less than full expectation. ${ }^{9}$ The High Court of Australia gave cautious support for this approach in Waltons Stores (Interstate) Ltd $\mathrm{v}$ Maher. ${ }^{10}$

\section{Damages for Distress and Disappointment}

The judge awarded the plaintiff 1,500 Euro for the distress, frustration and upset of losing a weekend's holiday in October 1997 when the defendants reneged on the agreement. It is also reasonably clear that this award was influenced by the judge's dim view of Mr O'Leary's hostile, aggressive and bullying attitude towards the plaintiff. ${ }^{11}$ So far as the disappointment of a lost holiday was concerned the judge based the award on the decision of the Court of Appeal in England in Jarvis v Swan Tours Ltd. ${ }^{12}$ The better approach would have been to seek guidance in the decision of the House of Lords in Farley v Skinner. ${ }^{13}$ There, Lord Scott indicated that awards for intangible losses like distress and disappointment were appropriate in cases where the protection of such interests was part of the agreed contractual performance or where such losses were foreseeable in the Hadley $\mathrm{v}$ Baxendale ${ }^{14}$ sense. $^{15}$ It is probable that the plaintiff's losses were part of the agreed contractual performance. There was no agreement as to whether flights should be for business or pleasure so it was probably understood by the parties that at least some of the plaintiff's travel would be for holidays. But the award of 1,500 Euro, at five times the judge's finding of the average return flight for two persons, does seem very much on the high side. ${ }^{16}$ It seems that Kelly $\mathbf{J}$ was awarding damages for the humiliating way in which Ryanair had breached the contract. It seems very doubtful whether this can be done and if that was the judge's approach it would have been better had it been more openly acknowledged. In Malik $\mathrm{v}$ Bank of Credit and Commerce International ${ }^{17}$ the House of Lords appears to have softened the line taken in Addis v Gramophone Co Ltd ${ }^{18}$ that damages cannot be awarded for the humiliating manner or stigma attached to an employee's dismissal. But that was in relation to an employment contract where dismissal may have a bearing on the employee's ability to obtain future employment. The same does not apply to contracts for air travel so this part of O'Keeffe v Ryanair $p l c$ is open to criticism.

\section{CONCLUSION}

This case attracted a lot of attention in the press and media. Its greatest significance is probably in the adverse publicity it attracted for Ryanair. But as this note may reveal it considered some very important legal issues as well.

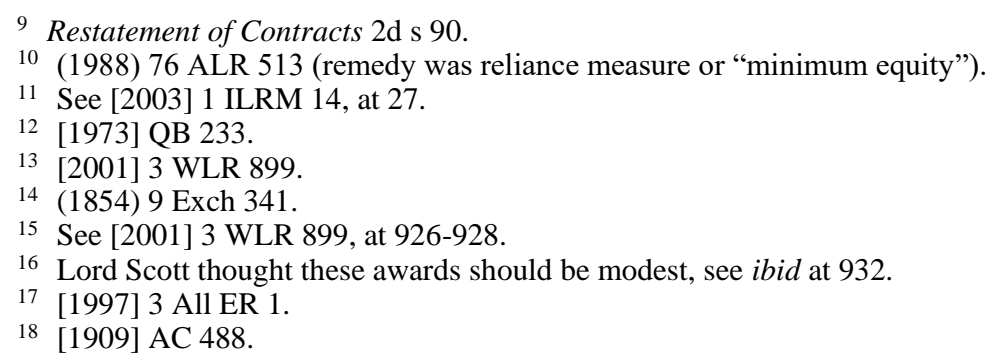

